\title{
Existence of Customary Law through Comparative Education between Dayak Ngaju Customary Law and National Law
}

\author{
Putri Fransiska Purnama Pratiwi' ${ }^{1}$, Suprayitno², Triyani $^{3}$ \\ ${ }^{I}$ Faculty of Law, Palangka Raya University, Indonesia \\ ${ }^{2}$ Faculty of Social and Political Sciences, Palangka Raya University, Indonesia \\ ${ }^{3}$ Faculty of Teacher Training and Education, Palangka Raya University, Indonesia \\ putri@law.upr.ac.id
}

\begin{abstract}
Resolving acts of adultery as the consequence of woman seducing a married man that sometime may lead to out of wedlock pregnany will not be sufficient to only be pursued through national legal channels in the point of view of the Dayak Ngaju tribe. National law regulates sanctions for adulterers/spouse poachers but does not consider the interests of legitimate wives who become the victims. This study aimed to educate the Dayak Ngaju tribe to have better knowledge regarding the local customary law and as a refinement material for the National Criminal Law.The research method used in this study was empirical research method conducted through interviews with damang and mantir adat in Palangka Raya City. The Dayak Ngaju Customary Law has distinct classification of adulterers. Therefore, all forms of actions committed by women who seduce other women's husbands are prohibited in Ngaju Dayak Customary Law. This is reinforced by different customary sanctions in each classification.The National Law has regulated the regulation regarding of homewreckers (husband poachers) in the latest Criminal Code Bill but does not formally regulate psychological recovery for wives who are the victims of infidelity.
\end{abstract} Keywords
comparison; dayak ngaju
customary law; national law

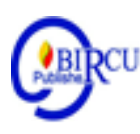

\section{Introduction}

In social life, law and society are two interrelated things that can never be separated or known as Ibi Ius Ibi Societas which can be translated to where there is a society there is law. Before the Criminal Code Bill regulates cohabitation and before the installment of adultery regulation in the National Penal Code, the Dayak Ngaju tribe in Central Kalimantan has its own rules about adultery and infidelity in their member's social life.

Traditional rights regarding customary law recognized by the State are not only material but include the rights of indigenous and tribal peoples to resolve legal problems that occur in their society using local wisdom regulated in the Regional Regulation of Central Kalimantan Province Number 1 of 2010 concerning Amendments to Regulations of Central Kalimantan Province Region Number 16 of 2008 concerning Dayak Customary Institutions in Central Kalimantan (Sanking 2016: 341).

The independent people who are seen in terms of their ability to maintain a local wisdom that will intersect with their role in protecting nature. Rattan as a typical plant for Dayaks in Central Kalimantan has given its own meaning when rattan has become a product so there is a review of the discussion in this analysis that women's empowerment is created because of the opportunity for entrepreneurship that is one of the pillars of society, especially the Dayak community. On the other hand, when the commodity of rattan has provided opportunities for increased income of Dayak society there is created an awareness 
to care more about protecting nature, this is also sustained to maintain identity as Dayaks who are also more concerned with the craft of local products. This is marked by the familiarity of rattan products that are easily found and used (Sarlawa, 2019).

In the Dayak Ngaju tribe in Central Kalimantan, marriage is noble and holy. The Dayak Ngaju tribe strongly avoids the disgraceful acts committed during marriages such as infidelity and adultery. The act of seducing other woman's husband while it is known that the man already has a legal wife is a disgraceful act for the Ngaju Dayak tribe. Infidelity or adultery committed by homewreckers (husband poachers) and even resulting in pregnancy won't be enough to be only pursued through national legal channels in the eyes of the Dayak Ngaju tribe.

As stated in Article 417 paragraph 1 of the Criminal Code Bill "Everyone who commits intercourse with a person who is not their husband or wife is convicted of adultery with a maximum imprisonment of 1 (one) year or a fine of Category II and the contents of Article 284 of the Criminal Code" Overtime, even though Article 27 BW applies to him, national law regulates sanctions for adulterers, but does put any consideration to the interests of the legitimate wife as the victim.

Based on the above background the authos were interested in raising an article entitled "The Existence of Dayak Customary Law through Comparative Education of Customary Law and National Law". The formulation of the problem raised is:

1. Customary Sanctions for Homewreckers (Husband Poachers) in the Dayak Ngaju Customary Law.

2. Criminal Sanctions for Husband Poachers in the National Criminal Law currently in force in Indonesia.

\section{Research Method}

This study belongs to empirical legal research. The subject of the study was conceptualizing law as actual behavior as an unwritten social phenomenon experienced by every individual in social life setting. The data source of empirical legal research is based on positive law and applicable customary law and then combined with observations in research sites.

The research was conducted in the Palangka Raya city as the capital of Central Kalimantan province. The research data consisted of primary data, namely various information and data obtained directly from the source, namely the interviewees in Kedamangan Jekan Raya Palangka Raya and secondary data, namely data obtained from sources that could support researchers such as archives or literature materials to support the research. The author used several literary books, articles, journals, laws and regulations relating to the theme that the author studied. The research instrument used was literature materials consisted of books from legal experts related to criminal law and criminal procedure, and the Dayak customary law related to the issues discussed.

\section{Results and Discussion}

\subsection{Customary Sanctions Applied to Homewreckers (Husband Poachers) in Dayak Ngaju Customary Law}

One essential characteristic of the Dayak Ngaju Customary Law is the essence of not to punish but to solve problems. This customary law based on not to hurt/harm the parties involve in the dispute but solve the problem, restore disturbed balance between them. The 
litigants are expected to resolve their problems peacefully and become kinship in the end. It aims to restore the balance of nature and provide legal education to all members of indigenous peoples including foreigners who live in Central Kalimantan (Marcos Tuan: 2019).

Threats and the imposition of sanctions are not only applied to humans but on animals and also the universe, even though the implementation is conducted by humans through rituals. Therefore, the sanctions are intended to reconcile the litigants. In addition, the sanction may also functions to resolve problems, restore the balance of nature in its relationship with universe, humans and the creator.

Based on the provisions of Article 32 of the Central Kalimantan Provincial Regulation Number 16 of 2008, it is stated that the types of sanctions can be categorized as follows.

1. Light Sanctions:
a) Advice,
b) Reprimand,
c) Apology.

2. Moderate Sanctions: Singer (compensation) and fines based on local wisdom.

3. Heavy Sanctions :

a) Excommunicated;

b) Expelled from indigenous peoples (exiled);

c) Title revocation.

Participation as feed-forward information and feedback information. With this definition community participation as a continuous two-way communication process can be interpreted that community participation is communication between the government as the policy holder and the community on the other party as the party who feels the direct impact of the policy (Sinujaji, 2019).

Various types of singer sanctions in the community can be grouped into 3 (three) groups, namely:

1) Penalty for damages in various forms such as payment of customary money to affected individual, surrendering customary items such as jars, gongs, mandau or spears as compensation for spiritual losses.

2) Fines to carry out traditional ceremonies (at the expense of pigs, chickens, cows, or buffalo) to cleanse the victim's mind, cleanse the community of all disgrace (taboo) as a form of apology from the perpetrators to spiritual ancestors.

3) Exile penalty (ostracized) from the community as punishment outside the legal system, a form of inner responsibility of the perpetrators for the violation of customary rules that they have commited.

The Dayak Ngaju tribe in Central Kalimantan is familiar with the term of customary sanctions called Jipen. Jipen is customary fines or sanctions imposed by the Customary Chief Damang based on consensus agreement in accordance with the contents of the Dayak Ngaju Customary Law for residents who commit mistakes or violate the customs of the tribe. The forms and sizes of Jipen vary according to the violations committed by that person (Suparan A.Gaman: 2019).

In carrying out their duties Customary Chief Damang is assisted by mantir adat as customary leader at the village level. A number of cases of violations of customary law both committed by the indigenous people and migrant communities in Central Kalimantan were resolved through a customary trial. The customary trial was led by a customary figure (Damang) and believed to be overseen by the spirits of the ancestors (Ibid).

The customary trial begins with rituals before the hearing as a sign of the commencement of customary justice. The judicial process is carried out in deliberation, 
sitting in a group in a room to disscuss the right and appropriate decision on the case. Furthermore, the men and women involved are sworn in customary way. This oath has fatal consequences if it is violated or the defendant provides false information. The karma of breaking this oath is really believed and feared by the Dayak Ngaju tribe.

Until today the Dayak Ngaju Customary Law that has been enforced to tribe still does not yet have full legal certainty because the damang in each region have their own considerations in making decisions based on customary cases they have handled or studied. In addition, the sanctions/Jipen that have been imposed may differ from one to another. Several factors that needs to be put in consideration such as the marital status of both parties, whether the first marriage or have been married before and assessed the social status of both parties.

The Dayak Ngaju Customary Law has distinct classification in terms of spouse poach, wanting to take a man who has legally married to other woman, according to the Judicial Guidelines of Central Kalimantan Customary Law on Violations of Customary Ethics include:

1. Habandung (adultery) mutual feeling;

2. Rape, sexual harassment;

3. Tungkun (take, steal wife/husband/soon to be wife/soon to be husband of other person);

4. Out of wedlock pregnancy (tulah/sumbang, sejajar, other people's wives, widows, bachelors and so on) (Central Provincial Council of Central Kalimantan Province 2015: $37)$.

Therefore, all forms of woman's actions to take the husband of other woman are prohibited in the Dayak Ngaju Customary Law. This is reinforced by different customary sanctions in each classification.

\subsection{Criminal Sanctions for Homewreckers (Husband Poachers) in the National Criminal Law currently in force in Indonesia}

Concerning the inter-ethnic relations in Kalimantan, surely, raises a condition, called as cohesion and segregation. The condition is normal in a society with a plural cultural background. Ethnic relation is part of the social structure of society in which consists of various complex social interactions. Of course, in establishing the social interaction in a plural society involves various elements of ethnicity identity (Suprayitno, 2019).

There is no special law that specifically regulates the acts of stealing another woman's husband in Criminal Law in Indonesia. The legal basis for entangling a husband poachers only based on Article 284 of the Criminal Law Law. Thus, the legal spouse of the adulterers who commits adultery and infidelity with another person can report their spouse on the basis of the article.

\section{Article 284:}

1. Threatened with a maximum imprisonment of nine months:

a. a married man who cheated, even though it is known that article $27 \mathrm{BW}$ applies to him,

b. a married woman who cheated, even though it is known that article $27 \mathrm{BW}$ applies to her,

c. a man who participated in the act, even though he knew the offender was married;

d. a married woman who participated in the act, even though she knew the offender was married and article $27 \mathrm{BW}$ applies to them

2. Prosecution is not carried out but on report of husband/wife who was being cheated, and when they apply article $27 \mathrm{BW}$, within a period of three months followed by a request for divorce or legal separation for that reason as well.

3. Regarding this report, articles 72,73 and 75 do not apply. 
4. Report can be withdrawn as long as the investigation in a court hearing has not begun.

5. If the husband and wife applies article $27 \mathrm{BW}$, the report is not heeded during the marriage has not been decided because of divorce or before the decision stating the legal separation becomes permanent.

Adultery articles can be used as a basis to punish husband poachers provided that there should be a report from the party/spouse who is harmed. According to the said provision, it can be interpreted that both the adulterer (as a woman who commits adultery with another's husband) or the man who has a legal wife (the husband that being seduced by husband poacher) can be punished under Article 284 of the Penal Code. Therefore, if a woman (X) makes a report that her husband (Y) has committed adultery with another woman (z), then not only $(\mathrm{Z})$ is reported but $(\mathrm{Y})$ is also guilty of adultery. However, usually a woman whose husband is stole by the homewrecker will instead focus her anger on the homewrecker and do everything possible to make the said homewrecker regret her actions.

Since January 10, 2018 the House of Representatives and the government have agreed to publish draft of Criminal Code Law draft. This draft expands the concept of adultery in the Criminal Code Law draft. According to article 484 paragraph (1) letter e of Criminal Code Law draft it has been stated that men and women who are not legally bound in marriage commit adultery (Kompas.com, 05/02/2018, 21:06 pm).

In paragraph 2 of this Article the House of Representative and the government have mutual understanding to tighten the provisions in Article 484 paragraph (2). The article regulates parties who can report or complain people suspected of committing adultery. Article 484 paragraph (2) of the Criminal Code Law draft states that criminal acts of adultery cannot be prosecuted except there is report from husband, wife or third party that had been wronged. Wronged third-party sentences are then replaced by husband, wife, parents, and children (Ibid). So that in the case of homewreckers (husband poachers) not everyone can report the act, the ones who are given the authority to make reports are husband, wife, parents and children.

Based on the above discussion the authors conclude that to resolve legal problems that occur today, particularly legal issues that are closely related to the morality of national law education is not sufficiently applied if it is not balanced with customary law education for students, especially for those students who are studying at the Faculty of Law.

\section{Conclusion}

1. The Dayak Ngaju Customary Law has distinct classification in terms of taking spouse of another person who has been legally married, according to the Judicial Guidelines of Central Kalimantan Customary Law on Violations of Customary Ethics include: Habandung (adultery) mutual feeling; rape, sexual harassment; Tungkun (taking wife/husband/future wife/future husband of another person); out of wedlock pregnancy (tulah/sumbang, sejajar, other people's wife, widows, bachelors and so on 3 . Therefore, any forms of actions of women who steal other women's husbands are prohibited in the Dayak Ngaju Customary Law. This is reinforced by different traditional sanctions depend on each classification.

2. National Law regulates the acts of homewreckers (husband poachers) in the latest Criminal Code Law draft but does not formally regulate psychological recovery for wives who become victims of adultery. The application of sanctions for the perpetrators until now is still a controversy because it is considered not as the realm of criminal law but the realm of civil (private). 


\section{References}

Dewan Adat Dayak Provinsi Kalimantan Tengah. (2017). Hadat 1894-Melihat Kembali 96 Pasal Hukum Adat dan Praktiknya Dalam Kehidupan Masyarakat Adat Dayak. Jakarta: Bumi Tama Gunajaya Agro.

Kuena. (2015). Simbol Dalam Upacara Adat Dayak Ngaju. Jurnal Bahasa, Sastra dan Pembelajarannya, Vol:5 No.2 (2015). https://ppjp.ulm.ac.id.

Muhni, D. A.I. (1994). Moral dan Religi Menurut Emile Durkheim \& Henri Bergson. Kanisius: Yogyakarta.

Putri F. P. P. (2019). Juridical Review Of Pelakor In Criminal Law Perspective. Morality : Jurnal Ilmu Hukum. Vol:5 No.1, 28-36.

Putri F. P.P., Suprayitno S, Triyani T. (2019). Upaya Hukum Untuk Menjerat Tindakan Pelakor Dalam Perspektif Hukum Adat Dayak Ngaju. Jurnal Cakrawala Hukum. Vol:10 No.2.

Sangking. (2016). Disertasi Doktor. Perlindungan Hukum Terhadap Tanah Adat Dalam Pembangunan Perkebunan Kelapa Sawit di Kabupaten Kota Waringin Timur Kalimantan Tengah Palangka Raya.

Sarlawa, R., and Adiwijaya, S. (2019). Local Wisdom-Based Women's Empowerment: Study of Rattan Weaving Craftsmen in the Betang Asi Credit Union Cooperative Business Group in Pulang Pisau Regency, Central Kalimantan Province. Budapest International Research and Critics Institute (BIRCI-Journal) : Humanities and Social Sciences, 2(4); 31-38.

Sinuhaji, T. U., Lubis, S., and Asfriyati. (2019). The Participation of Community in Tourism Development of the Muara Jambi Temple Complex, Muaro Jambi Regency. Britain International of Humanties and Social Sciences (BIoHS) Journal, 1(2); 62-71.

Suprayitno, Triyani, and Pratiwi, P. (2019). Strategy on the National Unity and Politic Agency (KESBANGPOL) in Maintaining Ethnicity and Religious Relations Based on Huma Betang Philosophy in Central Kalimantan. Budapest International Research and Critics Institute (BIRCI-Journal) : Humanities and Social Sciences, 2(4) 229-238.

Kristian E. (2018). DPR dan Pemerintah Sepakat Pasal Zina Tetap Diperluas Dalam RKUHP.https://nasional.kompas.com/read/2018/02/05/21064651/dpr-dan-pemerintahsepakat-pasal-zina-tetap-diperluas-dalam-rkuhp. 